\title{
\begin{tabular}{l|l}
\hline T $D D$ & Jurnal Inovasi, Evaluasi, dan Pengembangan Pembelajaran \\
\hline Journal of Innovation, Evaluation and Learning Development
\end{tabular}
}

\section{Peran Guru dalam Menerapkan Kurikulum 2013 pada Mata Pelajaran IPS Siswa Kelas III Sekolah Dasar}

\author{
Rizaluddin \\ Program studi Pendidikan Sejarah, STKIP Yapis Dompu \\ E-mail: rizaluddinaziz@gmail.com
}

Article History: Received: 2021-08-14 || Revised: 2021-08-20 || Published: 2021-08-20

Sejarah Artikel : Diterima: 2021-08-14 || Direvisi: 2021-08-20 || Dipublikasi: 2021-08-20

\begin{abstract}
The 2013 curriculum is a curriculum that combines several materials, this curriculum prioritizes understanding skill, character education, active discussions, and has highcourtesy, the purpose of this is to describe the role of teachers in implementing the 2013 curriculum on social studies subjects in SDN Negeri 3 Kempo.This research uses a qualitative approach with a type of phenomenalogy. This study uses two data, namely primary data and secondary data. Primary data obtained through observation techniques and strengthened by interview techniques. Then secondary data obtained through documentation techniques. Data analysis in this study uses descriptive research analysis which only collects, writes and concludes the responses from sources obtained by the author by interviewing and collecting documents related to this research. The results of this study illustrate that the role of the teacher in implementing the 2013 curriculum according to the teacher, what we need to prepare is a learning process plan and syllabus, textbooks, instructional media, LCD and laptop, apart from being a guide so that learning is well directed and correct, this is also as a support in order to achieve what the 2013 curriculum wants. 2013 curriculum learning prioritizes understanding skill, character education.
\end{abstract}

Keywords: Role, Teacher, Curriculum 2013

\begin{abstract}
Abstrak
Kurikulum 2013 merupakan kurikulum terpadu yang mengabungkan beberapa materi, kurikulum ini mengutamakan pemahaman skill, pendidikan karakter, aktif berdiskusi, dan memiliki sopan santun yang tinggi.Tujuan penelitian ini untuk mendekripsikan peran guru dalam menerapkan kurikulum 2013 pada mata pelajaran IPS di SD Negeri 03 Kempo. Penelitian ini mengunakan pendekatan kualitatif dengan jenis fenomenalogi. Penelitian ini menggunakan dua data yaitu data primer dan data sekunder. Data primer diperoleh melalui teknik observasi dan diperkuat dengan tehnik wawancara. Kemudian data sekunder diperoleh melalui teknik dokumentasi. Analisi data pada penelitian ini menggunakan analisis penelitian deskriptif yang hanya mengumpulkan, menulis dan menyimpulkan tanggapan dari sumber yang diperoleh penulis dengan cara mewawancarai dan mengumpulkan dokumen-dokumen yang berkaitan dengan penelitian ini, hasil penelitian ini memberikan gambaran bahwa peran guru dalam menerapkan kurikulum 2013 menurut guru, yang perlu kita siapkan yaitu RPP dan Silabus, buku paket, media pembelajaran, Lcd dan Laptop, selain sebagai pedoman agar pembelajarannya terarah dengan baik dan benar, ini juga sebagai penunjang agar tercapainnya apa yang diinginkan kurikulum 2013. Pembelajaran kurikulum 2013 mengutamakan pemahaman skill pendidikan karakter, aktif berdiskusi dan memiliki sopan santun yang tinggi
\end{abstract}

Kata kunci: Peran, Guru, Kurikulum 2013

\section{PENDAHULUAN}

Kurikulum 2013 ialah kurikulum yang terpadu sebagai suatu konsep dapat dikatakan sebuah sistem atau pendekatan pembelajaran yang melibatkan beberapa disiplin ilmu untuk memberikan pengalaman yang bermakna dan luas kepada peserta didik. Kurikulum 2013 lebih di tekankan pada pendidikan karakter, terutama pada tingkat dasar,yang akan menjadi pondasi bagi tingkat berikutnya (Mulyasa, 2014:6), Kurikulum 2013 inilah yang hendaknya diperhatikan setiap guru sebagaimanayang dilakukan oleh guru di SD Negeri 08 Kempo Kabupaten Dompu, dianjurkan agar setiap guru memiliki kemampuan untuk membangkitkan kreativitas belajar siswa sehingga siswa dapat mencapai prestasi belajar yang baik.Kegiatan belajar mengajar yang menarik dapat tercipta 
jika dalam suatu pembelajaran didukung oleh lingkungan belajar dan sarana/prasarana yang baik sehingga dapat menumbuhkan kemauan belajar pada diri peserta didik, Peran guru sangat luas diantaranya sebagai fasilitator, pemimpin, pendidik, motivator dan lain sebagainya.Agar penelitian ini dapat dilakukan dengan fokus, terarah permasalahan penelitian yang di angkat perlu dibatasi. Oleh sebab itu peneliti membatasi diri sebagai berikut, peran guru dibatasi sebagai fasilitator.

IPS (Ilmu Pengetahuan Sosial) Tema 7, Perkembangan Teknologi, Sub Tema, Perkembangan Teknologi Pangan, Peran guru sangat vital bagi pembentukan kepribadian, cita-cita, dan visi misi yang menjadi impian hidup anak didiknya dimasa depan, dibalik kesuksesan anak didik, selalu ada guru yang memberikan inspirasi dan motivasi besar pada dirinya sebagai sumber stamina dan energi untuk selalu belajar dan bergerak mengejar ketertinggalan, menggapai kemajuan, menorehkan prestasi spektakuler dan prestisius dalam panggung sejarah kehidupan manusia. Menurut Fakhruddin (2015: 35) bahwa "salah satu peran guru adalah terciptanya serangkaian tingkah laku yang saling berkaitan yangdilakukan dalam suatu tertentu, serta berhubungan dengan kemajuan perubahan tingkah laku dan perkembangan siswa menjadi tujuannya", Kurikulum 2013 adalah sebuah kurikulum yang mengutamakan pemahaman, skill, dan pendidikan karakter, siswa dituntut untuk paham atas materi, aktif dalam berdiskusi dan presentasi serta memiliki sopan santun disiplin yang tinggi.

Menurut H. Nana Sudjhana (2015) Kurikulum adalah peristiwa-peristiwa yang terjadi di bawa pengawasan sekolah, jadi selain kegiatan kulikuler yang formal juga kegiatan yang tak formal, Menurut Harry Widyastono, (2014: 1-6) Kurikulum adalah program program pendidikan bukan program pengajaran, yaitu program yang di rencanakan, di programkan dan di rancang yang berisi berbagai bahan ajar dan pengalaman belajar baik yang berasal dari waktu yang lalu, sekarang maupun yang akan dating, kurikulum ialah suatu program pendidikan yang berisikan berbagai bahan ajar dan pengalaman belajar yang di programkan, di rencanakan dan di rancang secara sistematik atas dasar norma-norma yang berlaku yang di jadikan pedoman dalam proses pembelajaran bagi bagi tenaga kependidikan dan peserta didik untuk mencapai tujuan pendidikan.

Kurikulum sebagai rencana pembelajaran, kurikulum adalah suatu sistem pendidikan yang di sediakan untuk mempelajarkan siswa, dengan program itu siswa melakukan berbagai kegiatan belajar, sehingga terjadi perubahan dan perkembangan tingkah laku siswa, sesuai dengan tujuan pendidikan dan pembelajaran, dengan kata lain, sekolah menyediakan lingkungan bagi siswa yang memberikan kesempatan belajar, itu sebabnya, suatu kurikulum harus di susun sedemikian rupa agar maksud tersebut dapat tercapai, kurikulum tidak terbatas pada sejumlah mata pelajaran saja, melainkan meliputi segala sesuatu yang dapat mempengaruhi perkembSangan siswa, seperti: Bangunan sekolah, alat pelajaran, perlengkapan, perpustakaan, gambar-gambar, halaman sekolah, dan lain-lain, Menurut Herry Widyastono (2014: 5) Kurikulum adalah suatu rencana yang di susun untuk melancarkan proses belajar mengajar di bawah bimbingan dan tanggung jawab sekolah atau lembaga pendidikan beserta staf pengajarnya, Menurut Ridwan Abdullah Sani (2015: 478) Dalam kosa kata arab, istilah kurikulum dikenal dengan kata manhaj yang berarti jalan yang terang atau jalan terang yang di lalui oleh manusia pada berbagai kehidupan, apabila pengertian manhaj atau kurikulum dikaitkan dengan pendidikan, maka berarti jalan terang yang di lalui pendidikan atau guru latih dengan orang-orang yang di didik atau dilatihnya untuk mengembangkan pengetahuan, keterampilan dan siskap mereka.

Disimpulkan dari penjelasan diatas bahwa kurikulum 2013 adalah kurikulum terpadu yang mengabungkan beberapa materi pembelajaran matematika, bahasa Indonesia, ppkn dan sebagainya, kurikulum 2013 mengutamakan pemahaman skill, pendidikan karakter, aktif berdiskusi, dan sopan santun yang tinggi, sedangkan Menurut Ridwan Abdullah Sani (2015: 24) mengatakan bahwa kurikulum terdiri dari fungsi penyusuain, fungsi pengintegrasian, fungsi diferensiasi, fungsi persiapan, fungsi pemilihan dan fungsi diagnostik.

a) Fungsi Penyusuain

Disini fungsi kurikulum harus mampu menata keadaan masyarakat agar dapat dibawa ke lingkungan sekolah untuk dijadikan objek pelajaran para siswa. 
b) Fungsi Integrasi

Disini kurikulum berfungsi mendidik pribadi-pribadi yang terintegrasi, oleh karena individu sendiri merupakan bagian dari Menurut Sanjaya (2018: 254) Indikator kurikulum 2013 sebagai berikut:

1) Peserta didik mudah memusatkan perhatian pada suatu tema tertentu.

2) Peserta didik dapat mempelajari pengetahuan dan pengembangan berbagai kompetensi dasar antar mata pelajaran dalam tema yang sama.

3) Pemahaman terhadap materi pelajaran lebih mendalam dan berkesan.

4) Kompetensi dasar dapat dikembangkan lebih baik dengan mengaitkan mata pelajaran lain dengan pengalaman pribadi peserta didik.

5) Peserta didik lebi merasakan manfaat dan makna belajar karena materi disajikan dalam konteks tema yang jelas.

6) Peserta didik lebi bergairah belajar karena dapat berkomunikasidalam situasi nyata, untuk mengembangkan suatu kemampuan dalam satu mata pelajaran sekaligus mempelajari mata pelajaran lain.

Guru dapat menghemat waktu karena mata pelajaran yang disajikan secara terpadu dapat dipersiapkan sekaligus dan diberikan dalam dua atau tiga pertemuan, waktu selebihnya dapat dipergunakan untuk kegiatan remedial pemantapan, atau pengayaan masyarakat, maka pribadi yang terintegrasi itu akan memberikan sumbangan dalam pembentukan atau pegintegrasian masyarakat.

c) Fungsi Diferensiasi

Kurikulum perlu memberikan pelayanan terhadap perbedaan diantara setiap orang dalam masyarakat. Pada dasarnya, diferensiasi akan mendorong orang berfikir kritis dan kreatif, sehingga akan mendorong kemajuan sosial dalam masyarakat. Akan tetapi, adanya diferensiasi tidak berarti mengabaikan solidaritas sosial dan integrasi, karena diferensiasi juga dapat menghindarkan terjadinya stagnasi sosial.

d) Fungsi Persiapan

Biasanya individu yang belajar pada suatu jenjang pendidikan mempunyai keinginan atau melanjutkan ke jenjang yang lebih tinggi, maka dalam hal ini kurikulum harus mampu mempersiapkan anak didik agar dapat melanjutkan studi meraih ilmu pengatahuan yang lebih tinggi dan lebih mendalam dengan jangkauan yang luas.

e) Fungsi Pemilihan

Perbedaan (diferensiasi) dan pemilihan (seleksi) adalah dua hal yang saling berkaitan, Pengakuan atas perbedaan berarti memberikan kesempatan bagi seseorang untuk memilih apa yang diinginkan dan menarik minatnya, kedua hal tersebut merupakan kebutuhan bagi masyarakat yang menganut sistem demokratis, untuk mengembangkan berbagai kemampuan tersebut, maka kurikulum perlu disusun secara luas dan bersifat fleksibel.

f) Fungsi Diagnostik

Fungsi ini merupakan fungsi kurikulum yang pada gilirannya akan mengetahui keberhasilan penerapan program-program pengalaman belajar yang diikuti oleh anak didik yang sejalan dengan upaya memahami bakat dan minat anak.

IPS merupakan kombinasi atau hasil pengfusian atau perpaduan dari sejumlah mata pelajaran seperti: geografi, ekonomi, sejarah, sosiologi, politik (Enok Maryani, 2016:4), IPS adalah ilmu pengetahuan yang memadukan sejumlah konsep pilihan dari cabang-cabang ilmu sosial dan ilmu lainnya, kemudian diolah menurut keterangan dari penjelasan dari prinsip pendidikan dan didaktik untuk dijadikan program pengajaran pada tingkat persekolahan, (Helius Syamsudin, 2016 :7) Menegaskan bahwa IPS merupakan perpaduan cabang-cabang ilmu sosial dan humaniora termaksud didalamnya agama filsafat, dan pendidikan, bahkan juga menyangkut aspek-aspek ilmu kealaman dan teknologi, (M.Numan Somantri, 2014) IPS merupakan bagian dari kurikulum yang mempumyai tanggung jawab untuk membantu siswa dalam mengembangkan pengetahuan, keterampilan, sikap, nilai yang diperlukan untuk berpartisipasi dalam kehidupan masyarakat baik ditingkat lokal, nasional, maupun global. 
Tujuan utama social studies adalah membantu generasi muda mengembangkan kemampuan pengetahuan dan keputusan yang rasional sebagai warga masyarakat yang beraneka budaya, masyarakat demokratis dalam dunia yang saling ketergantungan Somantri, (2014: 2), Helius Syamsudin, (2016: 5) Menyebutkan bahwa tujuan soscial studies (IPS) Adalah untuk mempersiapkan siswa menjadi warga negara yang baik dalam kehidupannya di masyarakat, dimana secara tegas ia mengatakan "to prepare students to be well-functioning citizens in a democratic society".

\section{METODE PENELITIAN}

Penelitian ini menggunakan penelitian kualitatif dengan pendekatan fenomenologi. Sebagai disiplin ilmu, fenomenologi mempelajari struktur pengalaman dan kesadaran, secara harfiah, fenomenologi adalah studi yang mempelajari fenomena, seperti penampakan, segalah hal yang muncul dalam pengalaman kita. Fokus perhatian fenomenologi tidak hanya sekedar fenomena, akan tetapi pengalaman sadar dari sudut pandang orang pertama atau yang mengalaminya secara langsung. Fokus model pendekatan fenomenologi adalah pengalaman yang dialami oleh individu, bagaimana individu memaknai pengalamannya tersebut berkaitan dengan fenomena tertentu yang sangat berarti bagi individu yang bersangkutan, oleh karena model pendekatan fenomenologi memfokuskan pada pengalaman pribadi individu, subjek penelitiannya adalah orang yang mengalami langsung kejadian atau fenomena yang terjadi, bukan individu yang yang mengetahui suatu fenomena secara tidak langsung atau melalui media tertentu (Ghony, 2014: 59), Kedudukan peneliti dalam penelitian kualitatif merupakan perencana, pelaksana pengumpulan data, analisis, penafsir data, dan pada akhirnya ia menjadi pelopor penelitian (Abu Ahmadi, 2014: 121), dalam penelitian kualitatif peneliti berperan sebagai pengamat penuh, partisipan penuh, pengamat dari dalam, Pengamat partisipatif, pewawancara mendalam dan peneliti partisipatif (Sukmadinata, 2018: 111 - 112), dalam penelitian ini peneliti hadir sebagai pengamat penuh dimana peneliti berada diluar situasi yang diamati dan tidak ada hubungan sama sekali antara pengamat dan yang diamati (Sukmadinata, 2018: 111).

\section{HASIL DAN PEMBAHASAN}

\section{A. Hasil Penelitian}

Pada saat perencanaan guru, untuk memulai proses pembelajaran berlangsung, guru harus mempunyai persiapan seperti silabus dan rencana proses pembelajaran (RPP) agar kegiatan pembelajaran mempunyai tujuan sehingga guru dapat lebih mudah memaparkan pada siswa tentang materi pembelajaran yang akan dijelaskan seperti pembelajaran matematika, dari data hasil dokumentasi dan wawancara.

a) Data Wawancara

Berdasrkan hasil wawancara peneliti dengan salah satu responden memberikan keterangan bahwa peran guru dalam menerapkan kurikulum 2013 sangatlah penting untuk diperhatikan Pada saat menjelaskan materi pembelajaran guru hanya menggunakan dua metode demostrasi dan penugasan pada saat simulasi pembelajaran.

1) Wawancara; (1)

“...peran guru dalam menerapkan kurikulum 2013 sangat perlu bagi siswa karena kurikulum itu adalah suatu tindakan atau pelaksanaan dari sebuah rencana yang disusun matang dan terperinci, maka guru sebagai agen pengerak perlu memberikan pemahaman yang baik terutama pada mata pelajaran IPS, apalagi pada materi lingkungan tentang bergotong royong, dengan cara menyuruh siswa agar belajar bukan di sekolah saja tetapi di rumah juga. ..."(W/H/20/07/2020).

2) Wawancara; (2)

“...menjadi seorang guru IPS harus selalu memposisikan dirinya sbgai panutan mulai dari menjaga kebersihan dirinya (penampilan), pintar dan menguasai materi yang diajarkan. ..."(W/H/21/07/2020).

3) Wawancara ; (3)

"...kesulitan guru dalam menerapkan kurikulum 2013 terletak pada sarana dan prasarana yang tidak lengkap seperti buku, Icd dan laptop...."(W/H/22/07/2020). 
4) Wawancara; (4)

"... menegur siswa harus dengan sikap ramah agar mereka bersikap sopan terhadap gurunya dan hindari menegur dengan cara yang kasar, membangkitkan dorongan kepada siswa untuk belajar, membentuk kebiasaan belajar yang baik, dan memberikan ganjaran terhadap prestasi yang di capai oleh siswa agar dapat merangsang untuk mendapat prestasi yang lebih baik di kemudian hari" (W/H/23/07/2020).

5) Wawancara;(5)

“...kurikulum 2013 adalah kurikulum terpadu yang dimana mengabungkan materi Bahasa Indonesia, IPS, Ppkn dan Matematika, sedangkan kurikulum KTSP memiliki standar kompetensi dasar dan guru dituntu mampu mengembangkan sendiri silabus dan penilaian sesuai kondisi sekolah dan daerahnya ...."(W/H/24/07/2020).

6) Wawancara;(6)

“...kurikulum 2013 lebih baik karena kurikulum ini mempermudah guru dalam pembelajaran dan menuntut guru lebih kreatif dan inovatif dalam menggunakan media pembelajaran..." $(W / S / 25 / 07 / 2020)$.

Temuan peneliti di lapangan yang berdasarkan hasil observasi dan wawancara kepada responden di SD Negeri 03 Kempo bahwa peran guru dalam menerapkan kurikulum 2013 pada mata pelajaran IPS ini sangat penting untuk diperhatikan dan menjadi seorang guru IPS harus senantiasa memposisikan dirinya sebagai tauladan bagi siswa dan masyarakat lainya, dari hasil observasi guru dan siswa pada saat proses pembelajaran berlangsung adalah sebagai berikut: Berdasarkan hasil penelitian yang peneliti amati pada saat proses pembelajaran yang disampaikan oleh guru yang berinisial "S" di SD Negeri 03 dompu peneliti mengamati langkah awal sebelum kegiatan pembelajaran berlangsung guru menyampaikan salam, memeriksa kehadiran siswa dan hal tersebut tertuang dalam RPP (Rencana Pelaksanaan Pembelajaran).

1. Observasi; (1)

"Berdasarkan hasil penelitian yang peneliti amati pada saat awal memulai pembelajaran yang sisampaikan oleh guru yang berinisial "S" di SD Negeri 03 Kempo peneliti mengamati cara guru dalam memulai proses pembelajaran mulai dari beliau salam dan bercakap dengan siswa dari cara tersebut peneliti dapat melihat bahwa kepribadian yang mantap dan stabil masih harus dan sangat perlu untuk diperhatikan lebih ekstra lagi, sebab seorang guru merupakan panutan bagi siswanya dan semua pergerakan dan ucapan guru akan selalu diperhatikan oleh siswa dan posisi/ cara guru didepan akan selalu diperhatikan dan diamati oleh siswa yang berada dibangku tempat mereka duduk.

2. Observasi; (2)

"dalam proses pembelajaran guru memberikan berupa catatan materi dan menjelaskan materi yang diajarkan dan sesekali guru memberikan contoh dan melakukan Tanya jawab dengan siswanya, proses pembelajaran tidak hanyak bertitik fokus pada pemberian materi semata dan tak kala sesekali bahkan harus sering kali seorang guru memberikan contoh yang berkaitan dengan dunia nyata, dan dalam proses KBM guru sesekali memperhatikan dan mempertahankan kepribadian dewasanya dalam bertindak.

3. Observasi; (3)

Temuan peneliti yang diamati pada saat melakukan penelitian di kelas III SD Negeri 03 Kempo yang disampaikan oleh guru yang berinisial "S" peneliti menenmukan bahwa kepribadian yang berwibawa sebagai seorang guru sangat penting untuk diperhatikan untuk meningkatkan kemauan dan minat belajar siswa, terutama dlam proses pembelajaran berlangsung sehingga siswa bersemangat dalam mengikuti proses pembelajaran dan wibawa sebagai seorang guru harus selalu diperhatikan dan dipertahankan agar siswa mengarhai dan menghormati gurunya dan segala perintah guru yang baik akan mau didengar dan dipatuhi oleh siswa.

4. Observasi; (4)

Berdasarkaan hasil penelitian terlihat jelas teknik guru menyampaikan materi IPS masih kurang bervariasi, seharusnya guru lebih kreatif dan inovatif dalam menggunakan media pembelajaran agar lebih menarik dan lebih mudah dipahami oleh siswa. 


\section{B. Pembahasan}

Berdasarkan analisis data pada bab sebelumnya terungkap bahwa peran guru dalam menerapkan kurikulum 2013 menurut guru selama ini merupakan kurikulum yang mengutamakan pemahaman skill, pendidikan karakter, aktifberdiskusi, dan memiliki sopan santun yang tinggi, selain sebagai tenaga pendidik, fasilitator, motivator, dan pemberi inspirasi bagi siswa, dalam proses pembelajara guru harus mampu menciptakan suasana nyaman sedemikian rupa agar siswa mampu memahami apa yang disampaikan dan mengemukakan gagasannya. Selain itu guru harus mampu melihat kemampuan atau skill yang ada pada dirisiswa dengan cara memberi tugas atau masalahkepada setiap siswanya, kemudian kita lihat kemampuannya dalam memecahkan masalah tersebut, dengan begitu kita bisa melihat kemampuan siswa dan mampu mengembangkannya, senada dengan Muzni Ramanto, Soemarjadi (2013:2) siswa yang bisa dikatakan sebagai siswa yang memiliki keterampilan merupakan siswa yang dalam mengerjakan atau juga menyelesaikan pekerjaannya itu dengan secara cepat dan benar, namun, apabila, siswa itu mengerjakan atau menyelesaikan pekerjaannya dengan cepat namun hasilnya itu tidak sesuai dalam artian salah maka siswa itu belum bisa dikatakan sebagai siswa yang terampil, apabila siswa itu dapat melakukan pekerjaan dengan benar serta sesuai apa yang diperintahkan walau lambat dalam menyelesaikannya, maka siswa itu bisa disimpulkan ialah sebagai orang yang terampil.

Untuk pendidikan karakter yang diutamakan adalah pengembangan jati diri siswa dengan cara memberikan pembelajaran bersifat rohanian dan mengamalkan ajaran agamanya, senada dengan $\mathrm{T}$. Ramli (2013) pendidikan karakter memiliki esensi dan makna yang sama dengan pendidikan moral dan pendidikan ahlak, tujuannya adalah membentuk pribadi anak, supaya menjadi pribadi yang baik, warga masyarakat, dan warga negara yang baik, Agar siswa aktif berdiskusi, kita buat kelompok dan setiap kelompok kita berikan tugas atau masalah yang akan dibahas oleh setiap kelompok ketika masalah terpecahkan kita suruh siswa menyampaikan gagasan yang didiskusikan dan mempresentasikannya. Senada dengan Martinis Yamin (2014:69) diskusi adalah suatu cara penyajian bahan pelajaran dimana guru memberi kesempatan kepada peserta atau kelompokkelompok peserta didik untuk mengadakan perbincangan ilmiah guna mengumpulkan pendapat membuat kesimpulan, atau menyusun berbagai akternatif pemecahan suatu masalah.

Agar siswa memiliki sopan santun yang tinggi guru sangat berperan aktif, karena setiap tindak tanduk guru akan diikuti oleh nsiswaya dan guru harus menjadi tauladan bagi siswanya. Senada dengan Putra Fernanda (2020:75) guna mempermudah dalam merealisasikan tujuan pendidikan untuk mengintegrasikan penanaman sopan santun kearah yang lebih baik, pada dasarnya pembentukan sopan santun dilakukan dengan unsur keteladanan dan pembiasaan bersikap mulia yang disandarkan pada tingkah laku guru, selain itu melalui keteladanan yang diperoleh dari lingkungan keluarga, dengan demikian peserta didik akan memiliki sikap atau perilaku teladan yang baik, beretika sesuai norma, dan lain sebagainya, adapun yang dilakukan dalam penanaman karakter sopan santun yaitu: (1) Keteladanan baik yang diperoleh dari lingkungan peserta didik, (2) Keluhuran moral, kematangan moral dan pengetahuan, (3) Perilaku sopan santun yang dicontohkan dari guru.

Menurut Sofan Amri (2014: 207) "bahwa proses pembelajaran merupakan tahapan-tahapan yang dilalui dalam mengembangkan kemampuan kognitif, afektif, dan psiskomotorik seseorang, dalam hal ini kemampuan yang harus dimiliki seorang siswa atau peserta didik. Salah satu peran yang dimiliki oleh seorang guru untuk melalui tahap-tahap ini adalah sebagai fasilitator, untuk menjadi fasilitator yang baik guru harus berupaya dengan optimal mempersiapkan rancangan pembelajaran yang sesuai dengan karakteristik anak didik, demi mencapai tujuan pembelajaran, sebagaimana yang diungkapkan oleh E, Mulyasa dalam Sofan Amri bahwa tugas guru tidak hanya menyampaikan informasi kepada peserta didik, tetapi harus menjadi fasilitator yang bertugas memberikan kemudahan belajar, untuk mampu melakukan proses pembelajaran ini guru harus mampu menyampaikan proses pembelajaran".

\section{SIMPULAN DAN SARAN}

\section{A. Simpulan}

Hasil penelitian ini memberikan gambaran bahwa persiapan proses pembelajaran yang dilakukan tidak lepas dari RPP dan Silabus, bukupaket, media pembelajaran, LCD dan Laptop, 
selain sebagai pedoman agar pembelajarannya terarah dengan baik dan benar, ini juga sebagai penunjang agar tercapainya apa yang diinginkan kurikulum 2013, pembelajaran kurikulum 2013 mengutamakan pemahaman skill, pendidikan karakter, aktif berdiskusi, dan memiliki sopan santun yang tinggi, tugas guru sebagai tenaga pendidik, fasilitator, motivator, dan pemberi inspirasi belajar bagi peserta didik, dalam proses pembelajaran guru harus menciptakan suasana nyaman sedemikian rupa agar siswa mampu memahami apa yang disampaikan dan aktif dalam bertanya dan mengemukakan gagasannya, selain itu juga guru harus mampu melihat kemampuan atau skill yang ada pada diri peserta didik dengan cara member tugas atau masalah kepada setiap peserta didik, kemudian kita lihat kemampuannya dalam memecahkan masalah tersebut, dengan begitu kita bias melihat kemampuan peserta didik dan mampu mengembangkannya, untuk membangun pendidikan karakter yang diutamakan adalah pengembangan jati diri peserta didik dengan cara memberikan pembelajaran bersifat rohanian dan mengamalkan ajaran agamanya, agar peserta didik aktif berdiskusi, kita buat kelompok dan setiap kelompok kita berikan tugas atau masalah yang akan dibahas oleh setiap kelompok ketika masalah terpecahkan kita suruh peserta didik menyampaikan gagasan yang didiskusikan dan mempresentasikannya, agar siswa memiliki sopan santun yang tinggi guru sangat berperan aktif, karena setiap tindak tanduk guru akan diikuti oleh peserta didiknya dan guru harus menjadi tauladan bagi peserta didiknya, Peran guru dalam menerapkan kurikulum 2013 sudah baik dalam hal melaksanakan tugas sebagai pendidik, fasilitator, motivator, dan pemberi inspirasi bagi peserta didik, meskipun masih ada kendala dari segi sarana dan prasarana yang tidak terawatt dan tidak ada sama sekali seperti leptop dan Lcd, karena pada dasarnya pemerintah menegaskan setiap sekolah wajib adanya 2 buah laptop dan 1 buah LCD, karena ini adalah penunjang agar tercapainya apa yang diinginkan kurikulum 2013.

\section{B. Saran}

Berdasarkan kesimpulan di atas maka penulis memberikan dan menyadari masih banyak kekurangan sehingga saya menyarankan beberapa hal sebagai berikut: (1) Kepada peneliti selanjutnya disarankan agar penelitian ini dapat dimanfaatkan sebagai acuan dalam melakukan penelitian selanjutnya, (2) Untuk dijadikan informan guru agar dapat menjadi motivator yang digemari siswa.

\section{DAFTAR RUJUKAN}

Ahmadi, Abu \& Narbuko Cholid. 2014. Metodologi Penelitian. Jakarta: Bumi Aksara.

Enok Maryani \& Helius Syamsudin. 2016. Pengembangan Program Pembelajaran IPS Untuk Meningkatkan Kopetensi Keterampilan Sosial. Jurnal Penelitian.Vol.9.No.15.

Moleong. 2016. Metodologi Penelitian Kualitatif Edisi Revisi. Bandung: Remaja Rosdakarya

Republik Indonesia. 2003. Undang-Undang Republik Indonesia Nomor 20 Tahun 2003 Tentang Sistem Pendidikan Nasional, Cet. I. Jakarta: Pn. Panca Usaha.

Ridwan Abdullah Sani. 2013. Pembelajaran Saintifik Untuk Implementasi Kurikulum 2013.Cet.3. Jakarta: Bumi Aksara

Sanjaya, W. 2018. Kurikulum dan Pembelajaran: Teori dan Paktik Pengembangan Kurikulum Tingkat Satuan Pendidikan. Jakarta: Kencana

Somantri, M. N. 2014. Mengagas Pembaharuan Pendidikan IPS. Bandung: PT Rosda Karya.

Sugiyono. 2014. Metode Pendekatan Kuantitatif, Kualitatif, dan R\&D. Bandung: Alfabeta.

Sukmadinata, Nana Syaodh. 2018. Metodepenelitian Pendidikan. Bandung: Remaja Rosda Karya.

Suryabrata, Sumadi. 1983. Metodologi Penelitian, Jakarta: PT Raja Grafindo Persada. 